\title{
Intercultural education in Europe: Policies, practices and trends
}

\begin{abstract}
:
European societies have become increasingly diverse as a result of legal and illegal migration flows, and educationists are facing the challenge of how to address the presence of migrant students. In recent years, there has been increasing activity at European level in the field of intercultural education despite the principle of subsidiarity. This article draws on 30 European level policy documents published within the last decade to analyse the dynamics influencing intercultural education in Europe. These include European Union institutions (such as European Commission, European Council, and Council of Ministers) and Council of Europe documents. Our discussions are situated within historical and contemporary European immigration policy developments. We argue that the main emphasis of recent European level policies and directives is on fostering social cohesion through incorporating migrant students. In so doing, European organisations have had to deal with arguments surrounding the legitimacy of European policy initiatives in the field of intercultural education.
\end{abstract}

Keywords: Intercultural education, Europe, policy, migration 


\section{The politics of immigration in Europe}

There are four main migration phases in post-war Europe. Firstly, the period immediately after World War Two until the 1973 oil crisis was characterised by large south-to-north flows originating from Turkey, Greece, Italy, Portugal and Spain, especially to Germany (e.g. Stalker 2002; Triandafyllidou and Gropas 2007). This was a period of reconstruction and industrial growth in central and northern Europe that was short of labour after the War. Secondly, after the oil price shocks in the early 1970s, the migration dynamics in Europe changed. As the European Communities pursued policies of economic integration, southnorth migration gradually declined. Restrictive immigration policies were characteristic of many countries, including Britain and France, as a prerequisite for the successful integration of those already admitted. Thirdly, the implosion of the communist regimes in Central and Eastern Europe (CEE) in 1989 led to increased east-to-west flows. Many CEE citizens started seeking better life chances and work opportunities in Western and Southern Europe (Wallace and Stola 2001; Favell and Hansen 2002). Fourthly, the beginning of the new millennium has seen a major shift in policy following the 9/11 attacks. As a direct result, security concerns closely related to migration became a priority. The concern, or the perception, that irregular migration was becoming uncontrollable was already being voiced by politicians and the media. Both the European Commission and a number of the EU member states announced policies regarding the recruitment of skilled and unskilled workers from outside the Union.

Other forms of temporary migration, especially in Central and Eastern Europe and in areas of the Mediterranean may be categorised as new forms of mobility rather than migration proper, according to length of stay and/or repetition of travel for employment reasons (Wallace 2002). They involve shuttle migration (repeated stays of a few months each, usually for informal work), suitcase migration (repeated trips of a few days or weeks each, mainly for trade and small business activities), and other petty trade and business activities related to the 
flourishing of 'bazaar economies' in Central and Eastern Europe and the wider Mediterranean basin. Migration is thus no longer simply the permanent movement from one country to another: it can be circular, it can mean travelling through a sequence of countries, it can even mean living in several countries at the same time. Especially because of improved physical transport, low-cost air travel and enhanced electronic communications, the concept of migration is being increasingly challenged.

These migration flows have been shaped and controlled by national and European policies, with an increasing emphasis on EU-level involvement. In the 1985 Schengen Accords, five countries agreed on the gradual abolition of checks at their common borders. However, as freedom of movement is one of the main objectives of the EU, the 1997 Treaty of Amsterdam incorporated the Schengen Accords into EU law. This effectively removed border controls between many European countries while hardening external frontiers, creating what is often referred to as 'Fortress Europe' (Bunyan 1991; Kofman and Sales 1992; Pieterse 1991; Stalker 2002). The 1999 Tampere European Council established the need for a common European policy on asylum and immigration (Council of the European Union 1999). Ten years later, the European Pact on Immigration and Asylum (Council of the European Union 2008) outlined five basic commitments: organise legal immigration to take account of the needs and priorities of member states; curb illegal immigration; establish more effective border controls; implement a European asylum policy; and create a partnership with the countries of origin to encourage synergy between migration and development.

The Directorate General for Freedom, Security and Justice has been actively engaged in preparing the ground for the development of a common EU immigration policy, issuing a series of relevant Communications and Council Directive proposals in recent years. Recent developments include the Council Directives on family reunification and on the status of long term residents (Council of the European Union 2003a), on common asylum procedures 
(Council of the European Union 2003b) and on the common efforts to combat illegal migration (Council of the European Union 2002). Although there has been progress in the building of a common EU migration policy, notably border control, directive proposals are often systematically watered down through the negotiations between Member States who seek to protect their national interests and national immigration policies. The events of 9/11 also contributed toward a turn to interculturalism emphasising what holds societies together rather than diversity and differences between communities within European societies.

These political developments have led to a new debate about multiculturalism and multicultural/intercultural education in Europe. A number of studies have looked at (factors affecting) educational performance of migrant students and strategies of integrating them in schools and societies at large (see Eurydice 2004, 2009, Heckmann 2008, Nusche 2009, OECD 2006, 2010), effects of intercultural education, diversity policies and measures (see Schofield 2006, Garreta Bochaca 2006, Gundara and Jacobs 2000), and perceptions towards religious and cultural differences and the impact on schools (see Jackson et al. 2007, Knauth et al. 2008, Valk et al. 2009). Five FP6 and FP7 projects (INCLUD-ED, EMILIE, EDUMIGROM, YIPPEE and ACCEPT PLURALISM) have also engaged with questions of how well new citizens from outside the EU integrate into society and what educational and political strategies promote social inclusion, tolerance and cohesion.

\section{Policy analysis of migration in Europe}

Our study reports on an analysis of the policy dynamics influencing intercultural education in the European context. As intercultural education does not only have pedagogical dimensions, we set out to critically examine the ways in which the discourse of intercultural education is interpreted, accepted, rejected and evolved in the European endeavour on the basis of the analysis of written policy documents. Therefore, drawing on the premise that policy is 'a 
changing series of texts whose expression and interpretation vary according to the context in which the texts are being put in practice' (Bowe et al., 1992: ix), we considered policy as a discourse. Policy-as-discourse is about 'the production of knowledge and evolution of practices through language and interaction, with policy embracing a set of tacit assumptions determined by its relationship to a particular situation, social system or ideological framework and representing a struggle over ideas and values' (Shaw 2010,1). We not only critically examined the historical development of policy discourses of intercultural education within the socio-political context of Europe, but also the values, interests and power mechanisms that influence the development of such discourses. We set out to examine how social processes and interactions shape discourses, which, in turn, influence policy development.

This research aimed to examine the context and content of educational policies and directives which have been initiated and/or developed at the European level (see Table 1 below). We analysed a wide range of policy-related documents from European institutions. The sampling strategy that guided the collection of these documents was purposive. In order to identify policy-related documents referring to diversity and intercultural education, we examined the official websites of the European Union and the Council of Europe and we used the provided search engines and electronic archives. We selected our documents according to the following criteria: (a) documents published by European bodies (institutions of the EU and the Council of Europe) that pertained to diversity and intercultural education, (b) documents published within the last decade, and (c) documents that are publicly available. In the event, a total of 30 documents were selected for data analysis. It should be noted here that these European bodies have very different areas of responsibilities and foci. While the EU currently has 27 member states, each of which has had to meet strict political and economic standards in order to gain entry, membership of the Council of Europe is determined solely on the basis of political concerns, and, as a result, the institution has a larger and more diverse 
set of 47 members. The Council of Europe is thus a less influential but more diverse supranational organization than the EU institutions. And while the European Council and the Ministers of Education represent national government interests, the Commission acts as an independent supranational body separate from (national) governments. As a result, our selected documents carry rather different weight which readers need to be aware of:

---- Put Table 1 about here ---

The inquiry aimed to analyse the dynamics influencing intercultural education in Europe. Firstly, we read our data closely and we also kept notes about our thought processes. We aimed to identify the 'story' of intercultural education in the European context in order to understand what occurred chronologically as if intercultural education was 'the product of a unique and "naturally unfolding" sequence of events' (Neuman, 2007: 335). Secondly, we began examining our data for groups of meanings, themes and assumptions and tried to locate how these were connected within a theoretical model (Creswell 2003). We thus examined our data looking for continuities, discontinuities, silences and contradictions in the discourses of intercultural education. This enabled us to identify similarities and differences in the definitions of intercultural education policy and policy goals that were proposed by the documents. In addition, Scott (2000: 29) asserts that educational documentation 'has a history, refers to other documents and educational discourses and policy moves'. Therefore we also examined the context within which each document was produced and we identified the intertextual relationships to contextualise the thematic categories. We studied our data in order to recognise the power dynamics and the historical and cultural contexts that have influenced the development of discourses of intercultural education in Europe. Thereafter, we studied the collected policy documents horizontally and following the two stages suggested 
by Erickson (1986), the inductive and the deductive. We continued the process of analysis and we divided the data into thematic categories: education and equal treatment; education and the social exclusion of youth; education and the integration of third country nationals (TCNs); and the latest trends on intercultural education policies. Finally, we began looking at our data in order to substantiate the emerging thematic categories with raw data.

\section{Interculturalism and intercultural education in Europe}

In recent decades, EU institutions have become a major supranational player in education with school-related issues shifting from a small concern of the EU to a major focus of the organisation's activities (Dale and Robertson 2009). Despite unifying calls from EU institutions and the Council of Europe for an intercultural dimension in the wake of increasing migration-related diversity, all EU countries have considerable autonomy in the field of education. EU actions therefore serve mainly to complement national level initiatives, for example through the Open Method of Coordination (OMC). This is an intra-European means of governance through which the EU identifies common challenges, pinpoints best practice, and encourages countries to review their existing national policies. Some scholars argue that the promotion of Europe and cultural diversity in education has helped transform nation-centred schooling approaches and curricula into more intercultural ones (Schissler and Soysal 2005). Others, however, hold that the EU 'still adheres to some of the key components of the nationalist discourse it seeks to evade' (Hansen 1998: 15), pointing to the ways in which EU education policies assume the idea that a common pan-European 'culture' is inherent and inherited, despite the rhetoric of 'unity in diversity'.

Despite the principle of subsidiarity, there has been considerable EU-level activity in education. Our study focuses primarily on the 'story' of intercultural policy development at the European level, rather than the policies and practices that have persisted at national levels. 
European societies rely on different models to address cultural and religious diversity in education, with different potential consequences for the experiences youth have in schools. For example, Germany, Greece and Ireland prefer the term interculturalism and intercultural education. In contrast, Britain, the Netherlands, Canada, the United States and Malaysia have historically worked with the concept of multiculturalism (see Faas, 2010). Furthermore, Faas (2011) who compared the geography, history and citizenship education curricula in Greece, Germany and England, argued that the relationship between European and multicultural values was rather different and dependent on the school subject. Whilst history was found to be ethnocentric in all three countries - albeit to varying degrees - Greek geography and citizenship curricula veered between ethnocentrism and Europeanism. In contrast, in England, macro-political notions of multicultural Britishness were reinforced in geography and citizenship education. Following national political trends, German curricula privileged national and European topics, but attempts were made to address diversity, particularly in geography. The work of Koopmans et al $(2005,2012)$ is equally indicative of the range of national policy-practice links, arguing that cross-national differences continue to exist due to different historical legacies and that these have not become smaller over the past three decades. While they found divergences in Europe in terms of citizenship acquisition, family reunification, access to public service employment, political rights, educational and other cultural rights, the only convergence was around anti-discrimination and expulsion.

Eldering and Rothenberg (1996) argue that the study of intercultural education entails the analysis of 'reality', ideology, official policy and practical implementation. While 'reality' concerns the presence of diverse ethnic, cultural or religious groups in a given society, ideology concerns the ways in which identity and culture are discussed and negotiated in a given socio-cultural context. In general, intercultural education encompasses the development and implementation of official policies and reforms that aim to promote 
equal education opportunities to culturally (and/or ethnically) diverse groupings, regardless of origin, social rank, gender or disability (see Banks and McGee Banks, 2009).

The literature illustrates an intense debate about intercultural education and the arguments for (Kincheloe and Steinberg, 1997) and against it (Stables, 2005). The acceptance or rejection of intercultural education does not deny the existence of intercultural societies. The different typologies of intercultural education attempt to conceptualise its goals and classifications (Banks and McGee Banks, 2009). However, in real-life situations (i.e. policy development and implementation at national level) these categories overlap and are always tentative. Multiculturalism is said to promote awareness about the cultural 'other' (Leclercq, 2002). The available literature reports various approaches to multiculturalism, including contributory, additive, transformative or social-action approaches (see Banks, 2006). The contributory and additive approaches suggest that the contributions of minorities or cultural content, respectively, are added to the curriculum, while its purposes and structure remain the same. Although the social-action approach represents the highest level of multiculturalism, the transformative approach is the actual level that teachers can reach in classroom. The focus on differences enhances multiculturalists' refusal to question the impact of these differences on the individuals' lives (Kincheloe and Steinberg, 1997). Thus they fail to establish social emancipation because of their inability to reveal and abolish institutional discrimination.

Interculturalism by contrast suggests that social-justice and equity values mobilise teachers towards the transformation of their pedagogy and curriculum in order to empower their marginalised students (Zembylas and Iasonos, 2010). Teachers aim to promote an education that challenges power relations and promotes social change (Tiedt and Tiedt, 2002). In this model, every individual takes action towards social emancipation. Intercultural education reveals the 'hidden' educational processes that perpetuate discrimination. It moves beyond the provision of plain understanding to the acquisition of skills that presuppose the 
transformation of these processes (Leclercq, 2002). Interculturalists stress the dynamic nature of cultures, which are an 'unstable mixture of sameness and otherness' (Leclercq, 2002: 6). Cultural boundaries alter and overlap to create a third space, within which locals and immigrants share a hybrid cultural identity. Interculturalism asserts that teachers and students ought to recognise oppression by promoting education for empathy, moral consciousness and examination of discrimination from the victim's perspective (Banks, 2006). In the remainder of this article, we analyse in turn the themes that emerged from our analysis.

\section{Education and equal treatment}

In its 2001 report to the European Council, the Education, Youth and Culture Council asserted that in order to fulfil the objectives of the Lisbon agenda, a vision of tolerance and solidarity needed to be conveyed by education systems. '[E]ducation and training systems have to lead people to accept that racism and intolerance have no place in our society; that discrimination (...) is unacceptable' (Council of the European Union 2001). Education systems should transmit values of tolerance and equality. The most central, legally binding EU instrument adopted in this spirit is the Council Directive of 29 June 2000 implementing the principle of equal treatment between persons irrespective of racial and ethnic origin. It provides that the principle of non-discrimination should be guaranteed, especially in the field of education. It stresses that ' $[\mathrm{t}] \mathrm{o}$ ensure the development of democratic and tolerant societies which allow the participation of all persons irrespective of racial or ethnic origin, specific action in the field of discrimination based on racial or ethnic origin should go beyond access to employed and self-employed activities and cover areas such as education' (Council of the European Union 2000).

Another crucial legal instrument in this spirit is Directive 2003/109/EC concerning the status of third-country nationals who are long-term residents, adopted in 2004 (Council of 
the European Union 2003a). Equal treatment in the field of education and vocational training is one of the crucial rights conferred by this measure to those qualified as third country nationals (TCNs) legally residing on EU territory for a period of at least five years. As explained in Recital 12 of the Directive, equal treatment is viewed as desirable for the TCNs to integrate fully into the society in which they live. It emphasises that '[i]n order to constitute a genuine instrument for the integration of long-term residents into [the] society in which they live, long-term residents should enjoy equality of treatment with citizens of the Member State in a wide range of economic and social matters, under the relevant conditions defined by this Directive'.

The contribution this could make to the development of democratic societies is apparent in the various policy instruments on education, which stress the potential of education to enable all children to play a full role in society. Education policies are increasingly oriented towards the promotion of 'active citizenship', which is considered to constitute an essential part of the learning process. As such, promoting the education of all not only purports to develop the individual in his/her personal capacity, but also amounts to helping sustain participative, democratic societies. This principle is especially obvious when looking at policy instruments targeted at specific groups, such as the Roma in Europe. For instance, in its 2005 Resolution on the situation of the Roma in the EU, the European Parliament considers better education for the Roma to be crucial to the advancement of the Romani community as a whole. It further asserts that the racism they suffer, which is apparent in their educational exclusion, triggers a weakening of the rule of law and of democracy, and hence the founding principles upon which the EU is supposed to be based.

One of the main characteristics of education systems as described in the EU policy instruments advocating the potential of education to promote democracy is that it should be provided on an equal basis to all. The Council Directive (2000/43/EC) on equal treatment 
between persons irrespective of racial or ethnic origin cited above emphasises that the participation of all in society can only be achieved after receiving equal treatment in all fields, including education. Education should thus be provided in a non-discriminatory manner and all children should be treated on an equal footing in the education system. This statement is undermined, however, by the distinctive discourses of the various institutional actors in the European debate.

While some European actors have advocated the inclusion in education policies of all migrant children irrespective of legal status, it is still not the rule across all EU official documents in which the administrative immigration status of the individual is central to the granting of rights and protections by the state and the EU. As a result, most EU policy instruments target TCNs only insofar as they are 'legally residing' in the EU (see Council of the European Union 2004). In some cases, access to education and vocational training on an equal basis will only be guaranteed after a certain length of residence or when a family member of a TCN enters on a special contract, such as for the purpose of highly qualified employment. These conditions are particularly of concern, as they hardly seem compatible with the principle of equal treatment of all, irrespective of racial or ethnic origin, or Article 14 of the Charter.

In the 2005 Resolution on the situation of the Roma in the EU, the European Parliament explicitly recognised the importance of mainstream education for all individuals, be they part of a minority group or not. It firmly rejected the racially segregated school systems in place in several member states and even called for the launch of desegregation programmes, not only to guarantee 'cohesion' with the rest of the class but also with respect to the content of the teaching provided by the education system. The rationale is to ensure that minorities are neither isolated from the rest of the class nor subject to lower standards of education. It is understood that equal opportunities in the field of education can be provided 
to all under these conditions. The rejection of segregating practices is increasingly an aspect of EU policy documents. This is illustrated by the 2008 Green Paper on Migration and Mobility (European Commission 2008); in the consultation procedure on this topic, the European Commission has underlined that the practices of segregation and tracking of children has not allowed friendships or societal bonds to develop between the children of migrants and their peers.

In 2005, the European Monitoring Centre on Racism and Xenophobia (EUMC) published the report Attitudes towards Migrants and Minorities in Europe. Drawing on data from the 1997, 2000 and 2003 Standard Eurobarometer surveys amongst EU citizens aged 15 and above as well as the 2003 European Social Survey which included a number of questions on xenophobic and discriminatory attitudes in European societies, the research found that sixty per cent of respondents in the EU-15 expressed the view that multiculturalism had certain limits as to how many people of other races, religions or cultures a society can accept, an opinion that has increased significantly since 1997. This view was less explicit in the ten new Member States (42\%). The Greeks (80\%), East Germans (75\%), Irish (72\%), West Germans (71\%) and British (68\%) most strongly supported the view that there are limits to a multicultural society whereas the Spanish (49\%), Italians (46\%), Swedes (41\%), Finnish (22\%) and most of the new Member States were less critical. In addition, the report showed that support for different forms of exclusion (i.e. resistance to multicultural society, limits to multicultural society, opposition to civil rights for legal migrants, favour repatriation policies for legal migrants, favour repatriation policies for criminal migrants) was more prevalent amongst people with lower education levels; economic prosperity appeared to lessen the perceived threat posed by immigrant minorities; and young people (aged 15 to 24) exhibited less support for ethnic exclusion than older people. 


\section{Education and social exclusion of youth}

Since 2000 , the social inclusion of youth has been set as a priority on the European agenda (Council of the European Union 2004). According to the Council, the involvement of young people constitutes an essential element of European integration. To achieve this, education and lifelong learning, voluntary activities and universal access to knowledge are considered to play a pivotal role. Notably, in its report on the Concrete Future Objectives of Education Systems, the European Commission asserts that a majority of member states do recognise the part that education systems can play in developing social cohesion (European Commission 2001). Under the Council's definition, social inclusion is understood to provide the necessary conditions for allowing youth to participate fully in both economic and social life (standard of living, quality of life, employment, training, education, housing, healthcare, culture, sport and leisure). The active participation of youth has from its early policy developments been viewed as better fostered through cross-sectoral cooperation, whereby this aim is addressed in various policy fields including education as well as labour. Most recently, the Commission has re-asserted its view that working towards the full participation of youth in society 'can be done more successfully through a transversal youth strategy'. Actions in the field of education are consequently seen as an essential element in enhancing youth participation in society.

In its Communication on the topic of making a European area of lifelong learning a reality, the Commission highlighted that all the member states agreed to four main objectives in relation to this policy: active citizenship, personal fulfilment, social inclusion and employability/adaptability. In this document, the understanding given to active citizenship refers as a whole as well as in their community. Hence, in its capacity to provide key competences, especially social and civic ones, education contributes to the development of active citizens. Indeed, it is apparent that schools are held to be the ideal venue for receiving 
education on citizenship, particularly through civic education. As highlighted by a Council recommendation on the key competences for lifelong learning, '[c]ivic competence equips individuals to fully participate in civic life, based on knowledge of social and political concepts and structures and a commitment to active and democratic participation' (Council of the European Union 2006).

Although the promotion of active European citizenship is a relatively recent concern in EU policy-making, Decision 1904/2006 establishing the programme 'Europe for Citizens' for the period 2007-13 to encourage active European citizenship sets out a detailed work programme for developing a sense of citizenship across the Union. In this vein, it stresses the need for this goal to be taken up in all policy areas. The role of actors in the field of education is highlighted as essential because their involvement is considered to facilitate a coherent and complementary action. Yet in terms of the impact of such policies so far, in its 2007 report on the progress towards the Lisbon objectives, the Commission recognised that 'the data available on education and active citizenship are limited in terms of scope, content, frequency and freshness' (European Commission 2007a). It appears that while this goal is defined as a policy priority, it has not yet been subject to specific investigation to assess the path and progress towards its fulfilment.

While the role of education in connection with social cohesion is increasingly acknowledged at the official EU level, most policy instruments do not expressly establish a nexus between the quality or characteristics of school systems and the inclusion of all youth, including those with a migrant and minority backgrounds. In recent years, the content of education provision has been addressed in relation to the promotion of participation and active citizenship. Along with the emphasis on the provision of a civic education curriculum, one of the key concepts put forward is the idea that learning to participate is better achieved by participation itself. According to the European Commission, the '[p]ossibilities offered by 
schools could be better exploited, by developing civic education curricula and making better use of schools' resources for organising activities that promote 'learning to participate by participating'.

In 2001, the Commission report's on the Concrete Future Objectives of Education Systems acknowledged member states' willingness to address the specific needs of those at risk of exclusion, such as 'people on low income, disabled people, ethnic minorities and immigrants'. Indeed, for the genuine promotion of social cohesion, education policies should explicitly take into account those considered vulnerable. Since then, this approach has often been highlighted throughout the development of an EU strategy for lifelong learning, i.e. that education systems should be tailored to the different needs of their students. The perceived challenge of education systems is to design approaches that will be inclusive and attract everyone into learning, including vulnerable groups and those with special difficulties.

\section{Education and the integration of third country nationals (TCNs)}

In the early days of the development of an EU policy on the integration of migrants who are TCNs, the objective entailed achieving fair treatment as well as the promotion of diversity. The EU strategy on integration has long consisted of highlighting the national competence over these policy areas and the positive impact of local measures involving key actors such as the providers of education. Indeed, the fundamental role of education in the integration process has been progressively ascertained with schools being seen as 'a forum in which to initiate the process of socialisation' of TCNs into the host society.

An EU framework on integration has been developed since 2002, especially through the exchange of information on national experiences and policies. The first annual report on migration and integration was published by the Commission in 2004 (European Commission, 2004). It aimed at providing an overview of policies on the admission and integration of 
TCNs at the national level. Among the common trends cited by the report was that of relying on education systems to convey certain skills perceived as vital for the purpose of integration. These skills include acquiring language skills and learning about 'basic norms and core values'. The common basic principles for immigration integration policy (CBPs) adopted by the Council in 2004 sought to specify what integration was supposed to comprise at the EU level. More specifically, among the 11 CBPs, the following are more relevant in relation to the themes addressed in this report. CBP No. 5 states that '[e]fforts in education are critical to preparing immigrants, and particularly their descendants, to be more successful and more active participants in society'. Furthermore, CBP No. 9 asserts that ' $[\mathrm{t}]$ he participation of migrants in the democratic process and in the formulation of integration policies and measures, especially at the local level, support[s] their integration'.

When looking at CBP No. 10, it is apparent that one of the main approaches followed consists of mainstreaming integration measures in other policies, including those dealing with education. This approach was followed up by the Commission in a 2005 Communication on a common agenda for integration and a framework for the integration of TCNs in the EU. The implementation of CBP No. 10 at the national level is visible in the Third Annual Report on Migration and Integration (European Commission 2007b) where it transpires from the analysis of national policies that seven out of the eleven CBPs may be achieved at the national level through education. Today, all of the EU policy instruments on integration establish a connection between educational inclusion and adaptation to the host society. By way of illustration, the 2007 Handbook on integration for policy-makers and practitioners provides that '[e]ducation is one of the principal areas of integration and has a central function in improving the life chances of immigrant children' (Niessen and Schibel 2007).

The political participation of TCNs is nonetheless a matter of sensitive debate at the EU level, as it is closely linked to issues of national sovereignty of the member states. In 
2000, the Commission - while recognising that 'the granting of civic and political rights to longer-term migrant residents (...) promotes integration' - also cites the length of stay in the country of residence as a condition for granting such rights. The connection that exists between political participation and integration is nonetheless highlighted in the Commission's statement that one can facilitate the other, hence referring to a close interdependence. The dominant approach in this debate is based on the recognition of the positive impact that inclusion in the education system may have on the integration of migrants. Perceived as critical to preparing immigrants to participate more actively in society, it is understood to benefit society as a whole. 'Education prepares people to participate better in all areas of daily life and to interact with others. Consequently, education not only has positive effects for the individual, but also for the society as a whole'.

In its Second Annual Report on Integration and Immigration, the Commission notes that the political participation of migrants is a subject that is increasingly of interest to the member states. Still, it appears that the participation of migrants is more often directed at the promotion of social cohesion through employment. Thus, future employment is the ultimate objective of providing adequate education for this group, which will enable them to participate. That notwithstanding, it is also assumed that economically active migrants will be more inclined to participate in societal processes including political participation. The Communication on immigration, integration and employment stated that with respect to '[p]articipation of immigrants in civic, cultural and political life: [t]his is important as it creates a sense of belonging and being a part of a community and of society in general. Such a feeling will in turn encourage immigrants to engage themselves in community life and other social, cultural and political activities'.

A certain trend is apparent when looking at the various policy documents referring to the provision of education to TCNs. While in the past high quality education, delivered in a 
non-discriminatory environment, was the main policy approach, the need to provide a more adapted education system has been progressively recognised in EU policy documents. Policies expressly targeted at the inclusion of TCNs have since been developed. With the intention of advocating education systems that would meet the specific needs of their students, it has always been stressed that the quality of the education received should not be less for TCNs than for nationals of the country.

In 2003, the Commission made significant efforts to propose paths for improvement. It suggested that diversity should be reflected in the curriculum. It also stressed that close cooperation between parents, immigrant communities and schools should be established (European Commission 2003). The 2005 European Parliament Resolution on integrating migrants through schools and multilingual education highlighted the importance of dialogue and exchange about both the host culture and the culture and history of the other community. In particular, it underlined the need to also involve children that are not yet of school age by developing pre-school education. Finally, the 2008 staff working document issued by the Commission on strengthening action and tools to meet integration challenges called for the establishment of 'effective school programmes for integration of immigrant pupils with targeted language classes and tuition, [as] initiatives promoting respect for diversity in the educational environment and support for teacher and parents are among the measures to be promoted to facilitate integration at school'.

At the same time, it is necessary to emphasise that the civic education component has gained importance in the integration debate by increasingly being interpreted as a 'requirement' or rather a mandatory condition for having access to certain rights. In addition, to some extent it has come to be associated with another aspect of European immigration and integration policies, namely that of integration requirements for TCNs in order to enjoy family reunification and long-term residency status. In certain countries, this requirement 
tends to take the form of integration tests and programmes, for which civic classes on the national institutions, principles and values of the country of residence are compulsory. Although this is mainly targeted at adults, it constitutes a significant reinterpretation of the fundamental right to education by turning such training into a condition for enjoyment of other fundamental rights, such as the right to enjoy private and family life.

\section{Latest trends on intercultural education policies}

In 2002, the Council of Europe launched a project called 'The New Challenge of Intercultural Education', which aimed to increase awareness of the necessity of including interfaith dialogue as an element of intercultural education, and focused on analysis of religion as a 'cultural phenomenon' (Council of Europe 2002). This was further highlighted in a project called 'Policies and Practices for Teaching Socio-Cultural Diversity' (Council of Europe 2005) whose main objective was to propose the introduction of common European principles for managing diversity at school. The Council highlighted that this should include the teaching of diversity through curricula, teacher training, and training for diversity in rural and urban areas. In 2007, ministers asked for the development of measures for inclusive education, particularly for the socio-culturally excluded; and called for the development of

key skills for social cohesion including interculturalism, multilingualism and citizenship (Council of Europe 2007). Most recently, the Council issued a White Paper on Intercultural Dialogue (2008) arguing that universal values - democracy, human rights and the rule of law - should be strengthened; intercultural competences should be taught and learned; spaces for intercultural dialogue should be created; and intercultural dialogue should be taken to the international level. Intercultural dialogue is seen as a tool to achieve a balance between cultural diversity and social cohesion. 
Similarly, the EU has responded to the educational challenges arising from migrationrelated diversity by making 2008 the Year of Intercultural Dialogue and adopting the Green Paper 'Migration and Mobility: challenges and opportunities for EU education systems' (European Commission 2008a). The document lists earlier findings from the Programme for International Student Assessment (PISA) and the Progress in International Reading Literacy Study (PIRLS) studies which show that migrants have lower educational achievement than their peers and that, in some countries including Germany, second-generation students have lower grades than first-generation students. The document also stressed that the learning of a host language is a way of creating social cohesion together with promotion of the heritage language as a way of respecting diversity, thus resembling the Council of Europe White Paper on Intercultural Dialogue.

The introduction to the Green Paper reaffirms that although educational policies remain a matter for member states, the combination of linguistic and cultural difference with socio-economic disadvantage presents an increasingly widely shared challenge in Europe. The European Parliament Resolution of 2 April 2009 on educating the children of migrants (European Parliament 2009) further provides for some reflection on policy-making in this field by emphasising aspects that could contribute to better school systems. It unequivocally states that the integration of migrants and minorities is favoured by education, as long as it is provided on an egalitarian basis, and as long as it follows an inclusive model. Along with other elements to be taken into consideration when designing more adapted school systems, the following are identified as central: partnerships between schools and communities, language learning, promotion of native language and culture, teaching for the parents, preschool provision, qualification recognition, partnerships with civil society, the integrative role of sports and other extracurricular activities, and training for teachers. The Green Paper and the European Parliament Resolution suggest a number of paths for creating better-adapted 
school systems. A common feature found in these documents relates to the rejection of segregation programmes and the positive role played by the involvement of the family.

\section{Discussion and conclusions}

Our review and analysis of key European level policy documents and developments in the field of intercultural education highlighted that there has been increasing European educational policy cooperation. This erosion, or at the very least softening, of the principle of subsidiarity which started with the Lisbon strategy in 2000 took on ever more tangible forms in the recent Europe 2020 strategy where education had a prominent place among the five headline targets (Council of the European Union 2010). Although the Commission continues to cooperate with member states via the OMC, the scope of that cooperation has widened significantly in recent years and now includes aspects such as intercultural education. This is evidenced in the number of policy documents and directives published during the past decade (see Table 1). At the same time, there has been increasing pressure both from national governments and international organisations such as the Council of Europe to identify benchmarks and indicators suitable for monitoring progress and quality across the diverse range of European education systems. National member states and school-level actors mediate European directives and guidelines in rather different ways, creating distinct educational contexts that shape the education of the new generation of youth.

There have been intense debates about the legitimacy of European activities in education including intercultural education. Some (Ruberti 2001; Trondal 2002) argue that the OMC marks the advent of supranational education policy. Others (Walkenhorst 2008) contend that it redirects educational policy formulation back to the national ministries and constitutes a move away from 'top-down' impositions despite a recent boost in European level activities. Since 2000, with the Lisbon strategy and Europe 2020 strategy, education has 
become increasingly intertwined with European economic competiveness and the OMC has become a widely accepted mode of policymaking in EU educational policy, both among many member states and the Commission. Yet, this new tool that appears to allow 'governing without power' is being increasingly used across a whole range of educational issues including equal treatment, social inclusion of youth, and integration of third country nationals. However, far from de-Europeanisation or handing back education policy to national ministries, EU institutions now seem to govern with softer power across a wider range of educational areas. EU summits that contribute to policy-shaping often do so by hammering out a common denominator that can be voted on unanimously, but which might be a long way from the concerns and interests of some individual member states. Rather than legally more problematic 'top-down' impositions, the OMC constitutes a smarter way of Europeanisation and expansion of EU educational policies in the twenty-first century.

In this context, the role of education in integrating migrants and enhancing social cohesion appears to have been accepted and recognised at official level. While the inability of current school systems to tackle this issue is now recognised, possible routes for modification have been suggested. These are expressly targeted at addressing the recent and present reality of increased 'human mobility' from within and outside Europe. The involvement of the EU is viewed as necessary by many, notably because one of the four freedoms guaranteed by the Union concerns the ability to move across the EU (the principle of free movement of persons) - a mobility that is at times hampered by the inadequacies of foreign school systems to deal with the specific needs of children on the move. The main emphasis of recent EU level initiatives is not on the impact that better schooling may have on the political participation of pupils with a migrant background but on social cohesion. The guiding logic of European policy documents is the better integration of migrants into society and more particularly into the labour market. And if it is expected that the political and social participation of this group 
will be enhanced by education that is more inclusive, this is only treated as a 'side effect' of the policies developed.

\section{References}

Banks, J. A. and McGee Banks, C.A. (eds.) (2009) Multicultural education: issues and perspectives (Needham Heights, Wiley).

Bowe, R. and Ball, S. with Gold, A. (1992) Reforming education and changing schools: case studies in policy sociology (London, Routledge).

Bunyan, T. (1991) Towards an authoritarian European state, Race and Class, 32(3), 19-27.

Council of Europe (2002) The new challenge of intercultural education: religious diversity and dialogue in Europe (Strasbourg, Council of Europe).

Council of Europe (2003) Declaration by the European Ministers of Education on intercultural education in the new European context (Strasbourg, Council of Europe).

Council of Europe (2005) Policies and practices for teaching socio-cultural diversity (Strasbourg, Council of Europe).

Council of Europe (2007) Final declaration: building a more humane and inclusive Europe: role of education policies (Strasbourg, Council of Europe).

Council of Ministers of Education (1988) Resolution of the Council and the Ministers of Education: Meeting within the Council on the European dimension in education of 24 May 1988, Official Journal of the European Communities, C 177.

Council of Ministers of Education (1993) Green paper on the European dimension of education (Luxembourg, Office for Official Publications of the European Communities). 
Council of Ministers of Education (2006) Recommendation of the European Parliament and the Council of 18 December 2006 on key competencies for lifelong learning, Official Journal of the European Union, L 394/10.

Council of Ministers of Education (2007) Council conclusions of 25 May 2007 on a coherent framework of indicators and benchmarks for monitoring progress towards the Lisbon objectives in education and training. Official Journal of the European Union C $311 / 10$.

Council of the European Union (1999) Tampere European Council: presidency conclusions. Available online at: from http://www.europarl.eu.int/summits (accessed 1 February 2012).

Council of the European Union (2000) Council directive 2000/43/EC of 29 June 2000 implementing the principle of equal treatment between persons irrespective of racial or ethnic origin, Official Journal of the European Union L 180.

Council of the European Union (2001) The concrete future objectives of education and training systems. Report from the Education Council to the European Council, 5980/01 EDUC 23.

Council of the European Union (2002) Proposal for a Council directive on the short-term residence permit issued to victims of action to facilitate illegal immigration or trafficking in human beings who cooperate with the competent authorities (COM 2002 071).

Council of the European Union (2003a) Council directive 2003/109/EC of 25 November 2003 concerning the status of third-country nationals who are long-term residents, Official Journal of the European Union, L 16/44.

Council of the European Union (2003b) Council regulation No 343/2003 of 18 February 2003 establishing the criteria and mechanisms for determining the member state 
responsible for examining an asylum application lodged in one of the member states by a third-country national.

Council of the European Union (2004) Resolution of the Council and of the Representatives of the Governments of the member states: meeting within the Council of 14 December 2000 on the social inclusion of young people, Official Journal of the European Union C 374/04.

Council of the European Union (2006) Recommendation of the European Parliament and of the Council of 18 December 2006 on key competences for lifelong learning, Official Journal of the European Union L 394/10.

Council of the European Union (2008) European pact on immigration and asylum. Available online at: http://www.euractiv.com/docad/pacteEN.doc (accessed 21 January 2012).

Council of the European Union (2009) Council resolution of 27 November 2009 on a renewed framework for European cooperation in the youth field (2010-2018). Available online at: http://ec.europa.eu/youth/pdf/doc1648 en.pdf (accessed 30 January 2012).

Creswell, J.W. (2003) Research design: qualitative, quantitative and mixed method approaches (London, Sage).

Dale, R. and Robertson, S. (eds) (2009) Globalisation and Europeanisation in education (Oxford, Symposium Books).

Directorate General for Internal Policies of the Union (2008) Intercultural education in schools: a comparative study (Brussels, European Parliament).

Eldering, L. and Rothenberg, J.J. (1996) Multicultural education: approaches and practice. in K. Watson, C. Modgil and S. Modgil (eds) Educational dilemmas: debate and diversity (London, Cassell). 
Erickson, F. (1986) Qualitative methods in research on teaching, in M.C. Wittrock (ed.) Handbook of research on teaching (New York, MacMillan).

Eurydice (2004) Integrating Immigrant Children into Schools in Europe (Brussels, EACEA). Eurydice (2009) Integrating immigrant children into schools in Europe: measures to foster communication with immigrant families and heritage language for immigrant children (Brussels, EACEA).

European Commission (1996) The white paper on teaching and learning: towards the learning society (Luxembourg, Office for Official Publications of the European Communities).

European Commission (2001) The concrete future objectives of education systems. Report COM 59 Brussels, 31.01.2001.

European Commission (2002) Detailed work programme on the follow-up of the objectives of education and training systems in Europe, Official Journal of the European Union, C $142 / 01$.

European Commission (2003) Communication on immigration, integration and employment. COM 336 Brussels, 03.06.2003.

European Commission (2004) Communication from the Commission to the Council, the European Parliament, the European Economic and Social Committee and the Committee of the Regions. First annual report on migration and integration COM 08.

European Commission (2007a) Progress towards the Lisbon objectives in education and training: indicators and benchmarks, Commission Staff Working Document SEC(2007) 1284, Brussels.

European Commission (2007b) Communication on the third annual report on migration and integration, COM 512 Brussels, 11.9.2007. 
European Commission (2008) Migration and mobility: challenges and opportunities for EU education systems. Available online at: http://ec.europa.eu/education/school21/com423_en.pdf (accessed 1 February 2012). European Monitoring Centre on Racism and Xenophobia (2005) Attitudes towards migrants and minorities in Europe (Wien, Manz Crossmedia).

Faas, D. (2010) Negotiating political identities: multiethnic schools and youth in Europe, Farnham: Ashgate.

Faas, D. (2011) The Nation, Europe and migration: a comparison of geography, history and citizenship education curricula in Greece, Germany and England, Journal of Curriculum Studies, 43(4), 471-92.

Favell, A. and Hansen, R. (2002) EU enlargement and east-west migration, Journal of Ethnic and Migration Studies, 28(4), 581-601.

Garreta Bochaca, J. (2006) Ethnic minorities and the Spanish and Catalan educational systems: from exclusion to intercultural education, International Journal of Intercultural Relations, 30(2), 261-79.

Gundara, J.S. and Jacobs, S. (eds) (2000) Intercultural Europe: diversity and social policy (Aldershot, Ashgate).

Hansen, P. (1998) Schooling a European identity: ethno-cultural exclusion and nationalist resonance within the EU policy of the European dimension of education, European Journal of Intercultural Studies, 9(1), 5-23.

Heckmann, F. (2008) Education and migration: strategies for integrating migrant children in European schools and societies (Brussels, European Commission).

Jackson, R., Miedema, S., Weisse, W. and Willaime, J.-P. (eds) (2007) Religion and education in Europe: developments, contexts and debates (Münster, Waxmann). 
Knauth, T., Jozsa, D.-P., Bertram-Troost, G. and Ipgrave, J. (eds) (2008) Encountering religious pluralism in school and society: a qualitative study of teenage perspectives in Europe (Münster: Waxmann).

Kofman, E. and Sales, R. (1992) Towards fortress Europe?, Women's Studies International Forum, 15(1), 29-39.

Koopmans, R., Statham, P., Giugni, M., Passy, F. (2005) Contested citizenship: immigration and cultural diversity in Europe (Minneapolis, University of Minnesota Press).

Koopmans, R., Michalowski, I and Waibel, S. (2012) Citizenship rights for immigrants: national political processes and cross-national convergence in Western Europe, 19802008, American Journal of Sociology 117(4), 1202-1245.

Lindblad, S. and Popkewitz, T.S. (2001) Education governance and social integration and exclusion. Project financed within the TSER programme. Brussels: DG Research, European Commission.

Neuman, W.L. (2007) Social research methods: qualitative and quantitative approaches (New Jersey, Pearson Education).

Niessen, J. and Schibel, Y. (2007) Handbook on integration for policymakers and practitioners (Brussels, DG Justice, Freedom and Security, European Commission).

Nusche, D. (2009) What works in migrant education? A review of evidence and policy options. OECD Education Working Paper, 22.

Organisation for Economic Cooperation and Development (2006) Where immigrant students succeed: a comparative review of performance and engagement in PISA 2003 (Paris, OECD).

Organisation for Economic Cooperation and Development (2010) Closing the gap for immigrant students: policies, practice and performance (Paris, OECD).

Pieterse, J. N. (1991) Fictions of Europe, Race and Class, 32(3), 3-10. 
Schissler, H. and Soysal, Y.N. (eds) (2005) The Nation, Europe and the world: textbooks and curricula in transition (Oxford, Berghahn Books).

Schofield, J.W. (2006) Migration background, minority-group membership and academic achievement: research evidence from social, educational and developmental psychology (Social Science Research Center, Berlin).

Scott, D. (2000) Reading educational research and policy (London, Routledge).

Shaw, S. E. (2010) Reaching the parts that other theories and methods can't reach: how and why a policy-as-discourse approach can inform health-related policy, Health, 14(2), $196-212$.

Stables, A. (2005) Multiculturalism and moral education: individual positioning, dialogue and cultural practice, Journal of Moral Education, 34(2), 185-197.

Stalker, P. (2002) Migration trends and migration policy in Europe', International Migration, 40(5), 151-179.

Triandafyllidou, A. and Gropas, R. (eds) (2007) European immigration: a sourcebook (Farnham, Ashgate).

Valk, P., Bertram-Troost, G., Friederici, M. and Béraud, C. (eds) (2009) Teenagers' perspectives on the role of religion in their lives, schools and societies: A European quantitative study (Münster, Waxmann).

Walkenhorst, H. (2008) Explaining change in EU education policy, Journal of European Public Policy, 15(4), 567-587.

Wallace, C. (2002) Opening and closing borders: migration and mobility in east central Europe, Journal of Ethnic and Migration Studies, 28(4), 603-625.

Wallace, C. and Stola, D. (eds) (2001) Patterns of migration in central Europe (London, Palgrave). 
Table 1: Overview of policy documents analysed for this study

\section{Council of Europe:}

The new challenge of intercultural education: Religious diversity and dialogue in Europe (2002)

Declaration by the European Ministers of Education on intercultural education in the new European context (2003)

Policies and practices for teaching socio-cultural diversity (2005)

Final declaration: Building a more humane and inclusive Europe: Role of education policies (2007)

\section{Council of Ministers of Education:}

Resolution of the Council and the Ministers of Education: Meeting within the Council on the European dimension in education of 24 May 1988 (1988)

Green Paper on the European dimension of education (1993)

Recommendation of the European Parliament and the Council of 18 December 2006 on key competencies for lifelong learning (2006)

Council conclusions of 25 May 2007 on a coherent framework of indicators and benchmarks for monitoring progress towards the Lisbon objectives in education and training (2007)

\section{Council of the European Union (European Council):}

Tampere European Council: Presidency conclusions (1999)

Council directive 2000/43/EC of 29 June 2000 implementing the principle of equal treatment between persons irrespective of racial or ethnic origin (2000)

The concrete future objectives of education and training systems (2001)

Proposal for a Council directive on the short-term residence permit issued to victims of action to facilitate illegal immigration or trafficking in human beings who cooperate with the competent authorities (2002)

Council directive 2003/109/EC of 25 November 2003 concerning the status of third-country nationals who are long-term residents (2003)

Council Regulation No 343/2003 of 18 February 2003 establishing the criteria and mechanisms for determining the member state responsible for examining an asylum application lodged in one of the member states by a third-country national (2003)

Resolution of the Council and of the Representatives of the Governments of the member states: Meeting within the Council of 14 December 2000 on the social inclusion of young people (2004)

Recommendation of the European Parliament and of the Council of 18 December 2006 on key competences for lifelong learning (2006)

European Pact on Immigration and Asylum (2008)

Council Resolution of 27 November 2009 on a renewed framework for European cooperation in the youth field (2009)

\section{European Commission:}

The White Paper on Teaching and Learning: Towards the learning society (1996)

The concrete future objectives of education systems (2001)

Detailed work programme on the follow-up of the objectives of education and training systems in Europe (2002)

Communication on immigration, integration and employment (2003)

Communication from the Commission to the Council, the European Parliament, the European Economic and Social Committee and the Committee of the Regions (2004)

Progress towards the Lisbon objectives in education and training: Indicators and benchmarks (2007)

Communication on the third annual report on migration and integration (2007)

Migration and mobility: challenges and opportunities for EU education systems (2008)

\section{Other policy papers:}

Attitudes towards migrants and minorities in Europe (EUMC, 2005)

Intercultural education in schools. A comparative study (DG IPOL, 2008)

Resolution on the situation of the Roma in the European Union of 28 April 2005 (European Parliament, 2005)

Resolution of 2 April 2009 on educating the children of migrants (European Parliament, 2009)

Total number of documents analysed: 30 